У. М. Селівачова, С. М. Стадніченко

ОСОБЛИВОСТІ ГЕОЛОГІЧНОГО СЕРЕДОВИЩА ТА ГРАНУЛОМЕТРИЧНОГО СКЛАДУ ВІДКЛАДІВ
РУКОТВОРНИХ ГНИЛЕЦЬКИХ ПЕЧЕР (УРОЧИЩЕ ЦЕРКОВЩИНА)

Yu. M. Selivachova, S. M. Stadnichenko

\title{
GEOLOGICAL ENVIRONMENT PECULIARITIES AND GRANULOMETRIC COMPOSITION OF HNYLETS MAN-MADE CAVES SEDIMENTS (TSERKOVSHCHINA DELL)
}

Наведено результати досліджень геологічного середовища печерного монастирського комплексу XI-XVI cT., що має охоронний статус. Зокрема, виявлено особливості гранулометричного складу вміщуючих порід та визначено літологічні типи відкладів. Встановлено зв'язок між поширенням алевритових і пелітових за складом відкладів та розташуванням потенційно небезпечних ділянок.

Ключові слова: Гнилецькі печери, геологічне середовище, гранулометричний склад.

Приведены результаты исследований геологической среды пещерного монастырского комплекса XI-XVI ст., имеющего охранный статус. В частности, выявлены особенности гранулометрического состава вмещающих пород и определены литологические типы отложений. Установлена связь между распространением алевритовых и пелитовых по составу отложений и расположением потенциально опасных участков.

Ключевые слова: Гнилецкие пещеры, геологическая среда, гранулометрический состав.

The results of geological environment investigations of protected artificial cave of XI-XVI century are given in the article. In particular the peculiarities of particle size distribution of adjoining sediments are established. The connection between the spreading of siltstone, pelitic sediments and emergency sites is established.

Keywords: Hnylets Caves, geological environment, particle size distribution.

\section{ВСТУП}

Поширення скельно-печерних комплексів, зокрема печерних скитів і монастирів у Південній, Східній і Центральній Європі, історично пов'язане з візантійською традицією чернечого печерництва. У межах сучасної України, залежно від особливостей геологічної будови окремих регіонів, збереглися комплекси середньовічних печерних храмових пам'яток, вироблених у вапнякових, крейдових, лесових породах, пісковиках. На території Києва та його околиць найвизначнішими є Києво-Печерські (Лаврські), Звіринецькі, Китаєвські та Гнилецькі печери в урочищі Церковщина. Останні розглядаються в контексті лаврської традиції печерництва як одна з філій Печерського монастиря [1, 2, 4]. На відміну від лаврських печер, які зазнали протягом XVI-XIX ст. грунтовного переобладнання, Гнилецькі зберегли свій первинний вигляд. Печерні монастирі Сeреднього Подніпров'я за своїми архітектурними особливостями відрізняються від пам'яток Візантії протяжними лабіринтами. На відміну від скельних монастирів візантійського кола, максимально відкритих до поверхні, пройдені в лесових суглинках та супісках штучні печери заглиблені в товщу гірських масивів.

Виникнення Гнилецького печерного монастиря XI-XVI ст. пов'язують з діяльністю Феодосія Печерського, одного із засновників КиєвоПечерської лаври. Гнилецький монастир, закладений на межі XI-XII ст. [4], спершу був печерним, а потім частково перенесений на поверхню, де побудували кам'яну церкву. Після монгольських набігів церкву було зруйновано, і виник топонім "Церковщина". у 1835 р. для прочан обладнали вхід у печери, а на початку XX ст. у "Церковщині" створено “Скит Пречистої». Тепер тут діє чоловічий монастир Різдва Пресвятої Богородиці. Досліджували печери П. Лашкарьов (1899), В. Ляскоронський (1925), співробітники Інституту археології АН УРСР (1980), Музею історії м. Києва (з 1991 р.) [7]. у 1987 р. фундаменти кам'яної давньоруської церкви і печери оголошені пам'ятками археології місцевого значення (№ 1112), а з 1992 р. пам'ятки урочища перебувають у віданні спеціалізованого відділу "Київ підземний» Музею історії м. Києва, ведуться археологічні дослідження і розчистка печер. 3 жовтня 2005 р.,

(c) У. М. Селівачова, С. М. Стадніченко, 2012 
коли в основному комплексі печер на окремих ділянках відбулися порушення цілісності склепінь та стіни, було призупинено відвідування печер. у 2011 р. відділом інженерної геології Інституту геологічних наук НАН України здійснювалися дослідження геологічного середовища пам'ятки.

Метою досліджень є визначення особливостей речовинного складу відкладів, що складають геологічне середовище печер, зокрема гранулометричного складу, який є найбільш чутливим індикатором динаміки процесу седиментації. Гранулометричний склад субаеральних відкладів, якими представлене геологічне середовище печер, визначається джерелом зносу уламкового матеріалу, способом і дальністю його транспортування, обстановкою осадконакопичення. Детальне вивчення гранулометричного складу вміщуючих порід по площі дозволяє встановити причини активізації небезпечних інженерно-геологічних процесів у печерах та надати рекомендації щодо їх усунення

\section{ОБ'ЄКТ ДОСЛІДЖЕНЬ, МАТЕРІАЛИ І МЕТОДИ}

Об'єктом досліджень є геологічне середовище Гнилецьких печер в урочищі Церковщина (територія санаторію МВС «Хутір Вольний» на Дніпропетровському шосе), розташовані на південній околиці м. Києва неподалік від сіл Чапаївка та Лісники (коорд. 50¹9'17" N, 30³2'06"Е).

Було вивчено 15 зразків, відібраних з основного комплексу Гнилецьких печер (рис. 1). Для порівняння використано результати гранулометричного аналізу чотирьох зразків (зр. 16-19) Смородинської печери (м. Київ), дослідженої нами раніше.

Гранулометричні дослідження теригенних порід виконані в лабораторії фізичних методів досліджень Інституту геологічних наук НАН України (лазерний аналізатор розміру частинок Mastersizer 2000, Malvern Instruments, Beликобританія). Діапазон вимірювання даного приладу 2000-0,02 мкм. Оскільки розмір частинок досліджуваних порід не перевищував 1000 мкм, була використана комірка аналі-

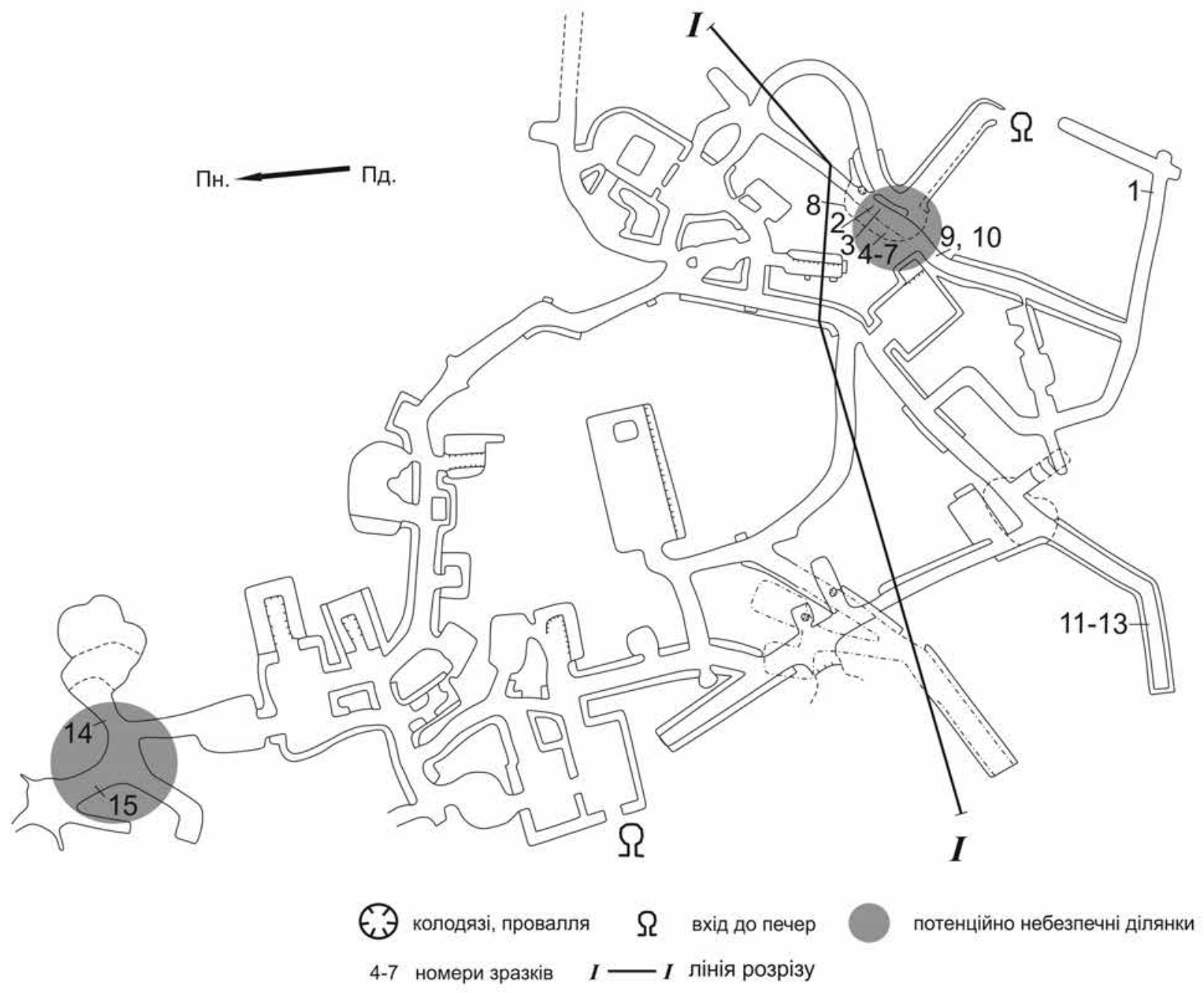

Рис.1. Схематичний план лабіринтів Північного комплексу Гнилецьких печер ( за [1]) 
зу суспензій Hydro SM: зразок диспергується шляхом додавання диспергуючої речовини та із застосуванням ультразвуку; закладається в комірку; доводиться до необхідної концентрації. Проводиться декілька циклів вимірювань (три вимірювання у циклі) залежно від кількості мінеральних видів у даному зразку. Перед кожним циклом задаються параметри мінерального виду та обирається розрахункова модель в залежності від форми частинок (мінеральний склад та морфологію мінеральних індивідів визначено за даними попередніх рентгендифрактометричних та електронномікроскопічних досліджень). Також вказується діапазон розмірів частинок, що складають пробу. Для зразків неоднорідної структури з метою підвищення достовірності було виконано вимірювання 2-5 окремих проб. Шляхом усереднення результатів усіх вимірювань отримується гранулометричний склад досліджуваного зразка.

\section{РЕЗУЛЬТАТИ ДОСЛІДЖЕННЯ ТА ЇХ АНАЛІЗ}

Історичне урочище Церковщина $€$ глибокою балкою на схилі корінного правого берега Дні- пра. В геоморфологічному відношенні крутий уступ правого корінного схилу долини Дніпра $€$ межею між Придніпровською височиною та Придніпровською низовиною. За структурногеоморфологічним районуванням місце розташування печер, представлене лесовим слабопідвищеним акумулятивно-денудаційним типом рельєфу, знаходиться в межах льодовикового району Північно-східної перигляціальної підобласті Лесової області Української платформної рівнини [3] в безпосередній близькості від границі з районом безморенних терас ДеснянськоДніпровської зандрово-алювіальної підобласті, де поширені алювіальні голоценові відклади.

В геологічній будові району виділяються нижній структурний поверх, представлений складно дислокованими та глибоко метаморфізованими кристалічними утвореннями архей-протерозойського віку, та верхній поверх, складений субгоризонтальними слабко дислокованими осадовими породами мезокайнозою. Нижній структурний поверх представлений ранньопротерозойськими кристалічними утвореннями звенигородського комплексу (ді-

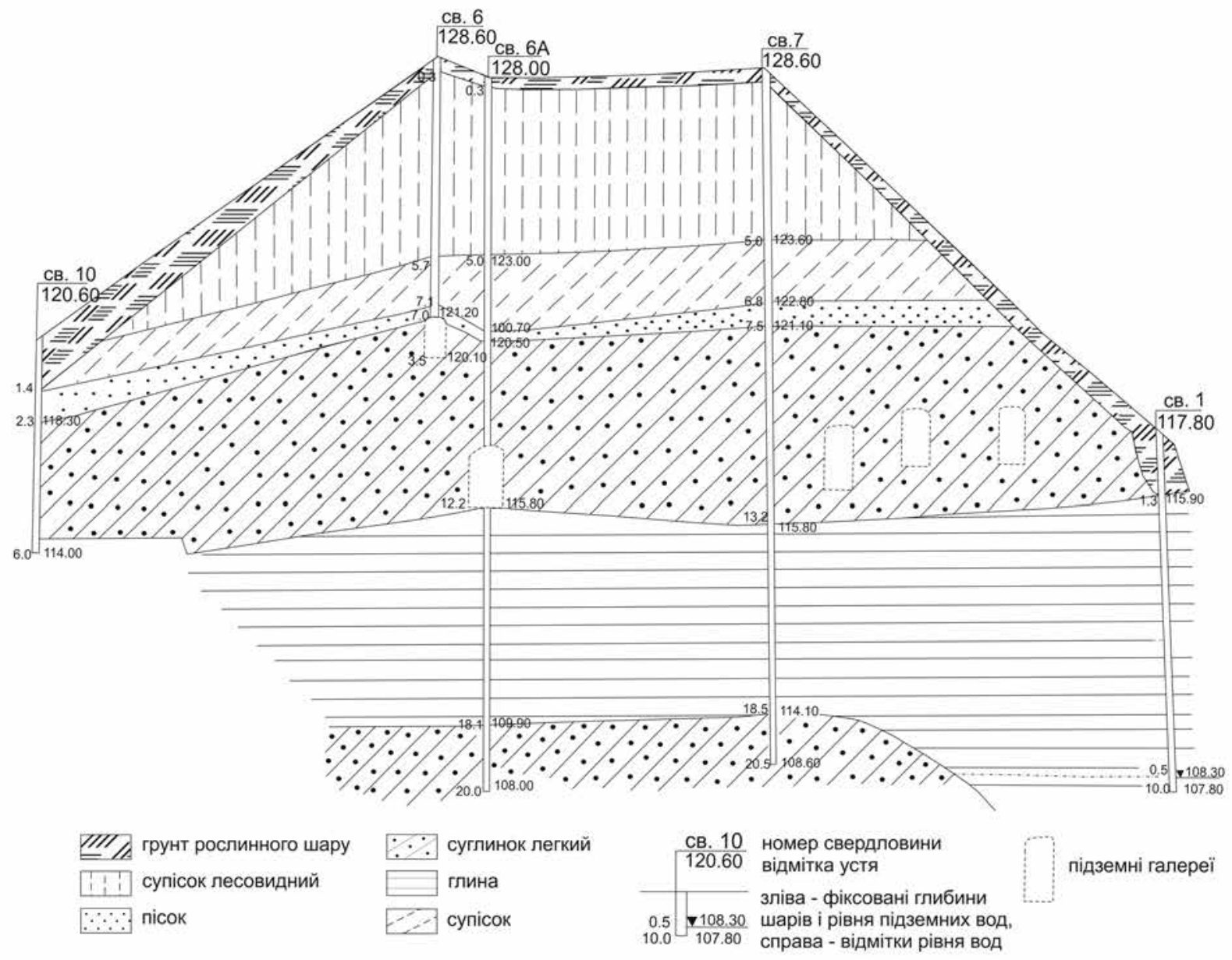

Рис. 2. Геологічний розріз по лінії I-I [6] 
орити і гранодіорити). У складі потужної товщі осадових відкладів встановлено утворення нижнього тріасу (дронівська світа індського ярусу: строкаті глини, алевроліти, пісковики та піски цегляно-червоні), середньої юри (орельська світа байоського ярусу: піски сірі з верствами глин, алевритів сірих, пісковиків, лінзами каолінів та бурого вугілля; підлужна світа батського-байоського ярусу: глини й алеврити коричнювато-сірі 3 поодинокими прошарками сидеритів; ніжинська світа батського ярусу: глини щільні, тонкошаруваті темно-сірі; ічнянська світа келовейського ярусу: глини й алеврити сірі, бурувато-сірі вапнисті) та верхньої юри (іваницька світа оксфордського ярусу: вапняки сірі, алеврити, алевроліти, мергелі різною мірою окременілі); верхньої крейди (буромська світа нижньосеноманського під'ярусу: піски, пісковики зеленувато-сірі крем'янисті); еоцену (канівська світа: піски зеленувато-сірі глауконіто-кварцові, алеврити і глини; бучацька серія: піски зеленувато-сірі глауконіто-кварцові з лінзами пісковиків; київська й обухівська світи: глини безкарбонатні, мергелі світло-сірі, піски карбонатні з фосфоритами) [5].

Властивості геологічного середовища Гнилецьких печер зумовлюються літологічним складом верхньої частини розрізу, складеної верхньонеоплейстоценовими полігенетич- ними, переважно елювіальними та еоловоделювіальними, лесовидними суглинками (рис. 2).

На території суміжних урочищ Церковщина, Гнилеччина, Гадючий Яр відомо два комплекси печерних споруд [1]: основний - Південний, "Феодосієва печера", та Північний (Гадючоярський). Досліджувалися Південні, закладені в межах абсолютних відміток 113,8-122,3 м, на глибині 3-15 м від поверхні в легких облесованих суглинках, потужність яких становить 5,7 м.

У морфологічному відношенні Гнилецькі печери являють собою замкнену систему ходів лабіринтового типу з відгалуженнями, невеликими залами та келіями. Більшу частину комплексу на початку XX ст. об'єднано у триярусний лабіринт (включає три нижніх яруси на глибині від 6 до 15 м) довжиною понад 350 м [4], різниця відміток крайніх верхньої і нижньої точокстановить 8,5 м. В межах лабіринту, крім церкви Св. Феодосія та коридорів, збереглися різні за розмірами приміщення кількох типів - келії, поховальні крипти, кімітірії для перепохованих кісток, господарські ями, каплиці [1]. Середня висота коридорів сягає 1,7 м., розміри келій $2 \times 1,5 \times 1,5 \mathrm{~m}$

Геологічне середовище печер представлене полігенетичними відкладами четвертинної системи: лесоподібним палево-жовтим ма-

Таблиця 1. Результати дослідження гранулометричного складу

\begin{tabular}{|c|l|c|c|c|}
\hline \multirow{2}{*}{$\begin{array}{c}\text { № } \\
\text { зр. Тип }\end{array}$} & \multicolumn{3}{|c|}{ Фракції, мм } \\
\cline { 3 - 5 } & Алеврит пелітовий & $1-0,1$ & $0,1-0,01$ & $<0,01$ \\
\hline 2 & Змішаний & 1 & 53 & 46 \\
\hline 3 & Пеліт алевритовий & 15 & 68 & 17 \\
\hline 4 & Алеврит піщаний & 1 & 65 & 34 \\
\hline 5 & Алеврит піщаний & 27 & 65 & 8 \\
\hline 6 & Змішаний & 18 & 71 & 15 \\
\hline 7 & Пеліт алевритовий & 3 & 38 & 59 \\
\hline 8 & Пеліт алевритовий & 4 & 37 & 59 \\
\hline 9 & Пеліт алевритовий & 2 & 36 & 62 \\
\hline 10 & Пеліт алевритовий & 2 & 45 & 53 \\
\hline 11 & Пеліт алевритовий & 1 & 30 & 69 \\
\hline 12 & Пеліт & 1 & 17 & 82 \\
\hline 13 & Пеліт & 1 & 19 & 80 \\
\hline 14 & Алеврит піщаний & 29 & 56 & 15 \\
\hline 15 & Змішаний & & 84 & 16 \\
\hline 16 & Алеврит & & 84 & 16 \\
\hline 17 & Алеврит & & 85 & 15 \\
\hline 18 & Алеврит & & & 12 \\
\hline 19 & Алеврит & & 50 & 18 \\
\hline
\end{tabular}


кропористим супіском, карбонатним супіском із залізо-марганцевими бобовинами; сірим супіском з лінзами і прошарками піску; піском пилуватим жовтувато-сірим, кварцовим, горизонтально-шаруватим; легким суглинком зеленувато-сірим, зі слідами озалізнення, що містить лінзи та прошарки піску, та еоценовими відкладами, представленими глиною зеленувато-сірою слюдистою 3 прошарком опіщаненої глини. Галереї печер закладені вище рівня підземних вод, який зафіксовано у свердловині №1 на рівні абсолютних відміток 108,3-108,5 м [6].

Дослідження показали, що за гранулометричним складом серед утворень, що складають геологічне середовище печер, переважають відклади алевритового та пелітового типів за Л.В. Пустоваловим [8], (див. таблицю).

До утворень алевритового типу серед вміщуючих порід основного комплексу Гнилецьких печер належить алеврит пелітовий з вмістом фракцій 1-0,1 мм - 1\%, 0,1-0,01 мм - 53$65 \%$, <0,01 мм - 34-46\% (зр. 1, 4) та алеврит піщаний 3 вмістом фракцій 1-0,1 мм 15-32\%, 0,1-0,01 мм - 50-71\%, <0,01 мм - 8-18\% (зр. 2, 5, 6, 14, 15). До утворень пелітового типу відносяться пеліт алевритовий з вмістом фракцій <0,01 мм - 53-69\%; 0,1-0,01 мм - 30-45\%, <0,01 мм - 53$69 \%$ (зр. 3, 7-11) та глина з вмістом фракцій 1-0,1 мм - 1\%, 0,1-0,01 мм - 17-19\%, $<0,01$ мм - 80-82\% (зр. 12, 13).

При порівнянні структурно-текстурних особливостей вміщуючих порід Гнилецьких та Смородинської печер встановлено переважання алевритового типу у складі останніх з вмістом фракцій 0,1-0,01 мм - 84-88\% та <0,01 мм - 12-16\% (зр. 16-19). Це свідчить про більш високий ступінь диференціації речовини при седиментації та кращі показники стійкості за рахунок відсутності частинок псамітової розмірності.

\section{ВИСНОВКИ}

За результатами дослідження гранулометричного складу зразків вміщуючих порід Гнилецьких печер встановлено утворення алевритового та пелітового типів. При порівнянні структурно-текстурних особливостей вміщуючих порід Гнилецьких та Смородинської печер встановлено переважання алевритового типу у складі останніх. За поширенням відкладів, представлених алевритом піщаним, виділено ділянки розташування потенційно небезпечних ділянок у північній та південно-східній частинах лабіринту Гнилецьких печер.

1. Бобровський Т. А. Підземні споруди Києва від найдавніших часів до середини XIX ст. (спелеоархеологічний нарис) / Т. А. Бобровский - К.: АртЕк, 2007. - 176 с.

2. Воронкова О.А. Київські печери: Путівник / О.А. Воронкова. - К.: Амадей, 2005. - 192 с.

3. Державна геологічна карта України масштаб 1:200000 Дніпровсько-Донецька серія, аркуш М-36-XIII (Київ): [пояснювальна записка] / [Ковальов О.Б., Матвеєв Г.Я., Пастухов В.В., Виноградов Г.Г., Охінько З.П.]. - К.: «Північгеологія", 2001. $-78 \mathrm{c}$.

4. Дятлов В. Церковщина. Повесть о забытой киевской святыне. / В. Дятлов. - Киев, 2001. - 398 с.

5. Ковальов О.Б., Матвеєв Г.Я., Пастухов В.В., Виноградов Г. Г., Охінько З.П. Державна геологічна карта України. М-б 1:200 000 Дніпровсько-Донецька серія, М-36-XIII (Київ). — К.: «Північгеологія", 2001.

6. Комплексное инженерно-геологическое и топогеодезическое исследование пироговских (Гнилецких) пещер города Киева: отчет по теме / МП «Питек", А. А. Белоус. - Киев, 1991.

7. Пам'ятки історії та культури України. Каталог-довідник. Зош. 2. Каталог-довідник пам'яток історії та культури України: м. Київ /Горбик В.О. (кер. авт. колект.), Гаврилюк Л.О., Денисенко Г.Г., Катаргіна Т.І. та ін. - К., 2007. - 277 c.

8. Пустовалов Л.В. Петрография осадочных пород. М.; Л.: Госнаучтехиздат, 1940. - 311 с.

Інститут геологічних наук НАН України, Київ E-mail: ulana_sel@ukr.net 